\title{
Traditional ecological knowledge on characteristics, conservation and management of soil in tribal communities of Pachmarhi Biosphere Reserve, India
}

\author{
C. P. Kala \\ Ecosystem \& Environment Management Indian Institute of Forest Management, Nehru Nagar, Bhopal - 462003 Madhya Pradesh, \\ INDIA Corresponding author: cpkala@yahoo.co.uk
}

\begin{abstract}
The problem of soil degradation has made the farmers to devise some indigenous practices and systems of land use since antiquity in order to maintain and restore the quality of land, which remains operational even today to maintain sustainable crop production. The present study, therefore, deals with the traditional ecological knowledge on soil characteristics and fertility along with the conservation and management of soil by the tribal communities in the Pachmarhi Biosphere Reserve (PBR) of India. Traditionally, the farmers in the study villages of PBR have classified the soil types mainly on the basis of soil texture, soil colour and its water retaining capacity. The study documented a total of 16 soil types, as classified by the villagers such as Bhurbhuria, Chikti, Kadialtori, Kamkaltori, Potini, Chikni, Kasai, Dadra and Barrimitti. Besides crop production, the soil was used for construction of house and pots, whitewashing and painting purposes. For conservation and management of soil, the farmers have adopted various traditional practices, which include crop rotation, burning of residues, planting forestry species, applying farmyard manure, and making land boundary. The study reflects that the traditional soil conservation and management practices in PBR are well knitted and interwoven with the cultures, belief systems and available resources.
\end{abstract}

Keywords: Traditional knowledge, soil classification, soil conservation, tribal communities, Pachmarhi Biosphere Reserve

\section{Introduction}

The constant interaction with biophysical environment has made the tribal communities and other forest dwellers to learn intricacies of nature and natural resources. Over the period of time, such interactions have led to evolution and accumulation of knowledge on the ecosystem properties that may be termed as traditional ecological knowledge. Traditional ecological knowledge has a historical continuity of resource use practice that is based on an integrated system of knowledge, practices, and beliefs including cosmology (Berkes et al., 2000). In 70 nations, over 370 million indigenous people have retained their cultural, social and economic characteristics that are distinct from those of the dominant societies in which 
they live (Schmidt and Peterson, 2009). Historically, along with collection of forest resources the huntergatherers or tribal societies have been practicing marginal agriculture. The agricultural practices of tribal communities follow some traditional norms including rituals, festivals and techniques. These practices are followed to increase the land fertility, soil conservation, moisture balance and pest control that subsequently have developed a wide range of site specific technologies (Haverkort, 1995; Cleveland, 1998).

In India, the traditional agricultural practices may vary across the agro-climatic zones. The diversity in soil types and diverse geographical conditions lead to diverse agricultural systems. The important forms of agriculture in India are settled, shifting and agroforestry based agriculture systems (Ramakrishnan, 2002; Kala et al., 2008). All these forms of agriculture are under pressure with the changing land use practices, increasing human population, and overexploitation of land resources that have subsequently resulted in the land degradation, particularly declining soil fertility and escalating soil erosion. Land degradation has been a problem ever since humans settled the land and started domesticating plants and animals (Sanders, 2004), hence the farmers had devised some indigenous practices and systems of land use to maintain and restore the quality of their lands, which remained an indispensable tool for sustained crop production (Tekwa et al., 2010). Unfortunately, these indigenous practices have seldom been recognized in the race for modernization and development; therefore, at present, most of such practices have reached to the verge of extinction.

However, the importance of traditional agricultural practices has been receiving attention for food security (Rajasekaran and Whiteford, 1992), quality control and for biodiversity conservation (Gadgil et al., 1993). Some agro-forestry based studies show that traditional agriculture enhances the soil quality and helps agriculture in a sustainable ways (Berkes, 1999; Ramakrishnan, 2002; Kala, 2012). There are studies available on the traditional agricultural practices elsewhere (Rajasekaran and Whiteford, 1992; Bonny and Vijayaragavan, 2001; Ramakrishnan, 2002; Kala et al., 2008) however there is no study available, especially on the characteristics, conservation and management of soil in the present study area of the Pachmarhi Biosphere Reserve (PBR) in India. Here in this context, the present study deals with the traditional ecological knowledge on soil characteristics and fertility along with the conservation and management of soil by the tribal communities in the PBR.

\section{Methodology}

\subsection{Study area}

The Pachmarhi Biosphere Reserve, one of the 15 biosphere reserves of India, lies between $20^{\circ} 10^{\prime}$ to $22^{\circ} 50^{\prime} \mathrm{N}$ latitude and $77^{\circ} 45^{\prime}$ to $78^{\circ} 56^{\prime}$ E longitude. PBR was established on March 3, 1999 in the Satpura Range of Madhya Pradesh. It spans over 3 districts of Madhya Pradesh - Hoshangabad, Betul, and Chhindwara. The total geographical area of PBR is $4926.28 \mathrm{sq} \mathrm{km}$, of which $524.37 \mathrm{sq} \mathrm{km}$ is under the core zone and remaining 4462. $93 \mathrm{sq} \mathrm{km}$ comprises the buffer zone (EPCO, 2001). PBR consists of three wildlife conservation units, the Satpura National Park (524.37 sq km), the Bori Wildlife Sanctuary (518.00 sq km), and the Pachmarhi Sanctuary (461.37 sq km). Satpuda National Park is designated as the core zone of PBR and the remaining area including the Bori and Pachmarhi sanctuaries constitutes the buffer zone. The rocky areas of Pachmarhi and Bori forests belong to the upper and lower Gondwana series, which contain sandstones and lime stones. In general, the temperature of PBR ranges from 11 to $42^{\circ} \mathrm{C}$ (Jayson, 1990; Kala, 2011).

PBR is endowed with rich plant and animal diversity. The forest vegetation of PBR is classified as subtropical hill forest and tropical moist deciduous forest (Jayson, 1990). A total of 30 species of thallophytes, 83 species 
of bryophytes, 71 species of pteridophytes, 7 species of gymnosperms, 1190 species of angiosperms have been reported to occur in PBR (Singh and Kaul, 2002). PBR is equally known for its cultural diversity, as it is inhabited by number of tribal and non-tribal communities. The major tribal group was Gond in the study area. Because of the numerical strength, the Gond tribes dominate the central parts of India and the Central Province was known as Gondwana state, as the Gonds ruled this part of India in the past. The social organization of the Gond reveals that they are divided into clans, such as, Arpanche, Bariba, Dhurwe, Erpachi, Karskoley, Sarada, Sivarsaran, Porta, Tekam and Wike. The livelihood of Gond and Mawasi tribes depends on the marginal agriculture, collection of minor forest produce and labour work. The major crops cultivated by these tribal groups are Oryza sativa, Triticum aestivum, Cajanus cajan, Paspalum scrobiculatum, Zea mays and Cicer arietinum.

About 75\% local people hold authorized land with land patta (Patta land is privately owned and can be sold and purchased freely by owner) and rest of the people live on encroached land and mainly collect minor forest produce for their livelihood.

\subsection{Survey methods}

For the present study, the villages in buffer zone areas of PBR, close to the boundary of Satpuda National Park, were surveyed. A total of 10 villages in buffer zone of PBR namely Sawarwani, Shahwan, Fatepur, Singhpur, Anhoni, Bandi, Deokoh Bodalkachhar, Khara and Taperwani were selected for intensive study of soil conservation practices and associated traditional ecological knowledge. The selected villages were dominated by tribal communities, mostly Gond and Mawasi with their off shoots. The questionnaire survey was conducted in the selected villages of PBR. In most of the villages, generally, the male members were available for interviews; however, female members were also helped during the interviews.
Through questionnaire information was collected on the traditional methods of soil identification, classification, fertility, crop specific selection of soil, traditional practices for maintaining soil fertility and soil conservation. Besides, the local people were encouraged to give their views and perceptions on soil with respect to the cultural, ecological and conservation perspectives. During the survey, different areas possessing different soil types were visited with the local knowledgeable people for understanding the soil characteristics and traditional practices and knowledge associated with them. Group discussions were also arranged to collect and verify the information on soil types, soil characteristics, traditional soil management practices, and associated belief systems. Participant observation methods were employed and information was also collected on traditional knowledge related to the soil by participating in various activities of the local tribal people.

\section{Results}

\subsection{Traditional classification of soil}

Traditionally, the soil characteristics paved the way for understanding the suitability of land for agriculture purposes. The farmers of the study villages have classified the soil types on the basis of soil texture, soil colour, water retaining capacity of soil and terrain types. The present study has documented 16 soil types as classified by the villagers in the study area, of these 10 soil types were classified on the basis of texture and 6 on the basis of soil colour (Table 1). Based on texture, the soil was classified into Bhurbhuria, Chikti, Kadialtori, Kamkaltori, Potini, Chikni, Kasai, Dadra and Barrimitti. The villagers have defined the term 'texture' in view of soil's capacity and quality to absorb the rain water.

Bhurbhuria soil was known to be one of the best fertile soils for crops. It was thick and fine loamy soil that absorbed rain water easily. 
Table 1: Soil types and their characteristics in the study villages of Pachmarhi Biosphere Reserve

\begin{tabular}{|c|c|c|c|}
\hline $\begin{array}{l}\text { Local name of } \\
\text { soil types }\end{array}$ & $\begin{array}{l}\text { Possible correlation with } \\
\text { standard soil } \\
\text { classification }\end{array}$ & Characteristics of soil & Major crops grown \\
\hline Bhurbhuria & $\begin{array}{l}\text { Fine loamy soil, black } \\
\text { cotton soil, deep/thick soil }\end{array}$ & $\begin{array}{l}\text { Black in color. Absorb water } \\
\text { easily and is considered good } \\
\text { fertile soil. }\end{array}$ & $\begin{array}{l}\text { Oryza sativa, } \quad \text { Triticum } \\
\text { aestivum, }\end{array}$ \\
\hline Chikti & $\begin{array}{l}\text { Salinity ingressed soil/ } \\
\text { Sodic soil }\end{array}$ & $\begin{array}{l}\text { Black in color. Quite hardy and do } \\
\text { not absorb water easily. Stack } \\
\text { with ploughing instruments. }\end{array}$ & $\begin{array}{l}\text { Paspalum scrobiculatum } \\
\text { and Corchorus spp. }\end{array}$ \\
\hline Kadialtori & $\begin{array}{l}\text { Valley fill/ coarse material } \\
\text { deposited in the foot of the } \\
\text { hills }\end{array}$ & $\begin{array}{l}\text { Particle size of soil is large. } \\
\text { Whitish in colour and have high } \\
\text { water retaining capacity. }\end{array}$ & $\begin{array}{l}\text { Short duration crops such as } \\
\text { 'Lalei' landrace of paddy, } \\
\text { Sesamum indicum }\end{array}$ \\
\hline Kamkaltori & $\begin{array}{l}\text { Pebbles and cobbles rich } \\
\text { soil cover }\end{array}$ & $\begin{array}{l}\text { Mostly stony. Particle size is big. } \\
\text { Generally, not used for long } \\
\text { duration crops. }\end{array}$ & $\begin{array}{l}\text { Zea mays, Phaseolus } \\
\text { mungo, Capsicum annum, } \\
\text { Lycopersicum esculentum }\end{array}$ \\
\hline Chiknimitti & Fine and glossy clay & $\begin{array}{l}\text { Reddish black in colour, Less } \\
\text { water retaining capacity. }\end{array}$ & Cereals and pulses. \\
\hline Rateli/ Dhadra & $\begin{array}{l}\text { Coarse texture, } \begin{array}{r}\text { deep } \\
\text { depth, } \\
\text { occasionally found }\end{array} \\
\end{array}$ & $\begin{array}{l}\text { Reddish black in color. Moderate } \\
\text { water holding capacity. Particle } \\
\text { size is relatively big, and stacks } \\
\text { with plough. }\end{array}$ & $\begin{array}{l}\text { Triticum aestivum, Cicer } \\
\text { arietinum, Oryza sativa, } \\
\text { Sesamum indicum, Cajanus } \\
\text { cajan }\end{array}$ \\
\hline Kasaimitti & $\begin{array}{l}\text { Pebbles and cobbles cover } \\
\text { soil }\end{array}$ & $\begin{array}{l}\text { High proportion of stones. } \\
\text { Difficult to till. }\end{array}$ & Not used for cropping. \\
\hline Potinimitti & $\begin{array}{l}\text { Clay soil found in pockets } \\
\text { (subsurface) }\end{array}$ & Buff colour & $\begin{array}{l}\text { Mostly used for } \\
\text { whitewashing and rarely for } \\
\text { cultivation. }\end{array}$ \\
\hline Kapewala & $\begin{array}{l}\text { Salinity ingressed thin } \\
\text { veneer of soil }\end{array}$ & $\begin{array}{l}\text { Black in colour. Less water } \\
\text { retaining capacity. }\end{array}$ & $\begin{array}{l}\text { Only short duration crops } \\
\text { including Sesamum indicum } \\
\text { and Cicer arietinum were } \\
\text { grown. }\end{array}$ \\
\hline Barimitti & Coarse grained loamy soil & $\begin{array}{l}\text { Reddish in colour. Predominated } \\
\text { by pebbles. Less fertile. }\end{array}$ & $\begin{array}{l}\text { Zea mays, } \\
\text { indicum }\end{array}$ \\
\hline Teloala & $\begin{array}{l}\text { Salinity ingressed soil, } \\
\text { poor in loam, thin soil }\end{array}$ & $\begin{array}{l}\text { Black in colour. Low water } \\
\text { retaining capacity. }\end{array}$ & $\begin{array}{l}\text { Paspalum scrobiculatum, } \\
\text { and Cicer arietinum }\end{array}$ \\
\hline $\begin{array}{l}\text { Kalimitti/ } \\
\text { Mariartori }\end{array}$ & Thick/deep and loamy soil & $\begin{array}{l}\text { Black in color and high water } \\
\text { retaining capacity. Easy to plough. }\end{array}$ & $\begin{array}{l}\text { Triticum aestivum, Cicer } \\
\text { arietinum, Oryza sativa }\end{array}$ \\
\hline Lalmitti & $\begin{array}{l}\text { Coarse grained/ lateritic, } \\
\text { thin soil cover }\end{array}$ & $\begin{array}{l}\text { Less water retaining capacity. } \\
\text { Mainly unfertile. Only used in } \\
\text { splashing the wall of the house } \\
\text { and also used for performing } \\
\text { various cultural activities. }\end{array}$ & $\begin{array}{l}\text { Generally not used for } \\
\text { cropping. }\end{array}$ \\
\hline Pirmitti & $\begin{array}{l}\text { Clay, found in pockets } \\
\text { (Paleo } \\
\text { body/channels) }\end{array}$ & Black in color & $\begin{array}{l}\text { Mostly used for plastering } \\
\text { and painting the house at the } \\
\text { time of festivals. }\end{array}$ \\
\hline Chhuimitti & $\begin{array}{l}\text { Clay, found in pockets } \\
\text { (subsurface) }\end{array}$ & Whitish in colour & $\begin{array}{l}\text { Mostly used for plastering } \\
\text { the house walls. }\end{array}$ \\
\hline Bamimitti & Clay, found in pocket & $\begin{array}{l}\text { Whitish in colour. Absence of } \\
\text { organic material }\end{array}$ & $\begin{array}{l}\text { Generally not used for } \\
\text { cropping }\end{array}$ \\
\hline
\end{tabular}


Because of its easy water absorbability, the farmers cultivated crops in such soil in the first monsoon in order to continue various cropping practices, as it stored large amount of rain water, which might hamper the subsequent necessary agricultural practices required for optimum yields. Wide cracks develop in this soil during the dry season. Though this soil was suitable to grow most crops, generally short duration crops were grown in this soil, such as, Paspalum scrobiculatum and Sesamum indicum. Besides, the farmers used to grow short duration land races of paddies like 'Batra' and 'Lalei' in Bhurbhuria soil type. Bhurbhuria appears blackish in colour. Chikti soil was also black in colour but different from Bhurbhuria due to its high proportion of reddish colour. Chikti was salinity ingressed moderately textured soil and had less water retaining capacity. Even in less rain fall, Chikti could be ploughed easily. The crops grown in Chikti were almost similar to the Bhurbhuria soil. Chikti soil occurs in areas close to forest. The forest biomass drained through rainwater also got mixed with this kind of soil and made it more fertile. Mostly jute (Corchorus spp) and Paspalum scrobiculatum were grown in Chikti soil by the villagers as it was considered good for these crops.

Kadialtori soil type had high water retaining capacity for longer period of time. It was composed of coarse material deposited in the foot of hills. It was whitish in colour, and difficult to dig, as it sticks to the tilling instrument. Generally, Kadialtori was not used for farming and mainly remained fallow. However, a few people attempted to grow Sesamum indicum and jute in this soil type along with paddies and ladyfinger (Abelmoschus esculentus). The local people believed that this soil type was less productive. Another soil type is Kamkaltori that has a high percentage of pebbles and cobbles. This soil type was not considered good for long duration crops, such as, Oryza sativa and Triticum aestivum. The farmers sometime used this soil type for cultivation of Zea mays, Phaseolus mungo, Capcicum annum and Lycopersicum esculentum. Chiknimitti was another soil type that was soft and easily got mixed with the rain water. Chiknimitti had less water retaining capacity. It was reddish black in colour and local people used to cultivate cereals and pulses of short period in this soil type. Chiknimitti was fine glossy soil and was also used for making pottery. Dhadra was the most common soil type and was predominately found in all the studied villages. In Dhadra, the sand proportion was quite low and it had moderate level of water holding capacity. The local people used to grow all types of crops in this soil type. Dhadra had coarse texture with occasional pebbles. Kasaimitti found in the study area was not used for cultivation due to its low fertility. It was difficult to plough this soil type because of high percentage of stones. Potinimitti was found in small patches and had buff colour. It was rarely used for cultivation. Kapewala was thin and salinity ingressed soil. It was black in colour and had low water retaining capacity. Barrimitti was also predominated by pebbles and was reddish in colour. This soil was considered less fertile and generally used to grow Zea mays and Sesamum indicum.

Besides texture, traditionally the soil was also classified on the basis of its colour by the local people such as Teloala, Mariartori, Lalmitti, Pirmitti and Chhuimiti. Teloala soil was blackish in colour and easily got stacked with digging instrument while tilling. The water retaining capacity of this soil was quite low. It was thin, salinity ingressed and poor loamy soil. Local people cultivated crops like Oryza sativa, Triticum aestivum, Paspalum scrobiculatum, and Cicer arietinum in this soil type. Teloala soil type was perceived more fertile as it yielded good crops. Mariartori soil type was also black and mostly occurred in and vicinity of the forest. It was thick and loamy soil. Local people considered it more fertile. The local people viewed that water flowing through the forest brought the organic materials to the adjacent forest land areas hence made such soil more fertile. They cultivated most of the varieties of crops including short and long duration in this soil type. The other soil types, such as Lalmitti was reddish, Pirmitti was blackish and Chhuimitti was whitish in colour. Another soil type, Bamimitti, whitish in colour, was also considered less 
fertile soil and difficult to plough even during rainy season due to its hardy nature. Hence people avoided growing crops in this type of soil.

\subsection{Traditional uses of soil}

Besides agricultural purposes, the local people have also accumulated knowledge on the use of soil for house construction, pot making, whitewashing and painting purposes. To decorate houses they mainly used 3 different soil types, such as, Lalmitti, Pirmitti, and Chhuimitti. These soils were generally not used for cultivation, however, in Khara and Taperwani villages the local people cultivated crops in Lalmitti, as these two villages were predominated by this soil only. Since Lalmitti had low fertility, the local people have made it fertile by applying high quantity of organic materials like cow dung, ash and decomposed leaves of plants. The local people of Sawarwani and Shahwan villages pointed out that this soil has been traditionally used for painting house walls. Lalmitti had wide cultural significance, as during most of the festivals people brought this soil not only for re-layering and painting houses but also used it for making marriage stage, and also splashing the places where the villagers worship their village deities. In order to make soil ready for painting and splashing, the collected soil was mixed with water. In addition, the cow dung was also mixed in proportion of $1 / 4$ of the soil. A piece of cloth was used to police the house wall by using this soil.

Pirmitti was used to splash the house floor. This soil was blackish in colour. Like the Lalmitti, cow dung was not added in Pirmitti before splashing. Besides house, this soil was used to splash the sacred places. Pirmitti was found in some limited places. Chhuimitti was found in a few localities near Shahwan, Singhpur and Anhoni villages that was whitish in color. It was extensively used by the villagers in splashing the houses. Since it was available on a few sites, the local people had made quarries on such sites that had 30 to 40 feet depth. Mostly the soil inside quarry remained wet hence the soil got dried after collection by making egg shaped structure (locally called as 'gola').

The house splashing method was similar to that of Pirmitti and Lalmitti. Chhuimitti was also sold in the local market. About $11 \%$ of people interviewed have admitted that they used to sell this soil in the market at the rate of ' $2 /$ - per $\mathrm{kg}$ of soil.

\subsection{Conservation and management of soil}

From preparing land for cultivation to sowing seeds and harvesting crops the farmers in the study villages of PBR remained cautious and thus had adopted some soil conservation and management practices from antiquity. The following traditional practices have been documented during the present investigations, as adopted by the local farmers for maintaining the soil fertility.

\subsubsection{Tillage system and fallow period}

Tilling of soil was dependent on the type of soil. For example, Bhurbhuria, Chikni, Teloala and Mariartori were tilled lightly to retain the soil moisture, whereas Dhadra, Potinimitti, Kamkaltori and Kadialtori tilted relatively higher than the former soil types. It was believed that if Bhurbhuria, Chiknimitii and Teloala were tilled deeply, the seedlings of respective crops took longer time to germinate, and subsequently affected by heavy rainfalls. In study area, traditionally people have been practicing two kinds of crops - rabi crops and kharif crops. To recoup the land fertility, they had 2 months fallow period between rabi and kharif crops.

\subsubsection{Burning residues}

The land was prepared for cultivation by removing stones and before sowing seeds, they cut down and burnt small bushes and weeds as it was believed that such practices enhance the soil fertility. People gathered the remains of one crops at three or four localities within the farm depending on the size of farmland and burnt it to ashes before starting the 
next crops. The local people often scattered ashes in their agricultural field with a view to enhance the soil fertility as well as to protect the crops from the pests. The bushes and leaves of trees available adjacent to the agricultural field were also collected and burnt to ashes that was mixed up with soil while tilting the land for cultivation. If some unwanted grasses and bushes have dominated the land, the people dug out the land deeply in order to uproot such grasses and bushes, which are finally burnt to ashes.

\subsubsection{Planting forestry species}

Traditionally, the local people have been using plant material as farmyard organic manure and also practiced agro-forestry system. The local people perceived that earlier due to abundant deciduous tree species in and around their agricultural field, there were good accumulation of organic manure in the forms of continuous deposition and subsequent decomposition of leaves and twigs. At present, though the agro-forestry system has declined a few species of Madhuca indica, Azadirachta indica, Shorea robusta, Tectona grandis, Dendrocalamus strictus, Adina cordifolia and Phyllanthus emblica were still found in the agricultural field.

\subsubsection{Crop rotation}

In all the studied villages, crop rotation was regularly followed. The local people viewed that repetition of same crops decreased productivity because of change in soil nutrients for respective crops. They also avoided growing some crops together in the same agricultural field, as they believed that each crop not only required diverse climatic and soil conditions, but also got benefited from each others. Some crops were grown alone as a monoculture cropping, as these crops might not perform well with other crop species. There were also some norms for growing species together as mixed cropping systems; however, there were preference over associated species. For example, Sesamum indicum was not grown with Zea mays as the former needed high water compared to later one. In one calendar year, Oryza sativa was cultivated in one field and in the next year they cultivated there Cicer areatinum. Cicer areatinum was harvested by cutting its aerial parts and its underground part was not removed that increased soil nitrogen and subsequently the productivity of crops.

\subsubsection{Making land boundary}

To demarcate the individual land boundary, the local people generally used stones and logs. Dendrocalamus strictus, Hardwickia binata, Zizyphus mauritiana and Anogeissus latifolia were frequently used for this purpose. These robust plant stems were erected and tied with rope made up of Ischaemum angustifolium or Butea superba to support the erected stems. Besides, Lantana camera, Vitex nigundo, Hardwickia binata, Dendrocalamus strictus, Ipomoea carnea and Opuntia sp were used as bio-fencing. Apart from protecting crops from wild animals and livestock, the land boundary protected soil from erosion and maintained the soil nutrients and fertility.

\subsubsection{Checking soil erosion}

In the studied villages of PBR, the local people practiced cultivation in both plain and slope land areas. The intensity of soil erosion was higher in the slope land areas. The slope degree and its composition also influenced soil erosion. The local people stop and divert the water to croplands that drained through forestland, as it is considered more fertile. Traditionally, they have designed different methods to check soil erosion and also to retain soil nutrients. They check soil erosion by making trenches and terraces in the field including mulching (Table 2). Of the different methods of soil protection, making of bunds/ wooden poles was still adopted and practiced by highest number of respondents (63\%), followed by mulching (57\%; Table 2). Traditionally, the small plots or terraces are made for maintaining uniform distribution of water in the agricultural land. 
Table 2. Responses on the traditional soil conservation methods of farmers in Pachmarhi Biosphere Reserve

\begin{tabular}{|l|c|c|c|}
\hline \multirow{2}{*}{ Parameters } & \multicolumn{3}{c|}{ Responses (n=128) } \\
\cline { 2 - 4 } & Yes & No & Not answered \\
\hline Making entire field into small plot & 49 & 52 & 27 \\
\hline Mulching & 73 & 23 & 32 \\
\hline Making of small bunds/rock/wooden poles & 81 & 34 & 13 \\
\hline Growing of grass along the border & 36 & 63 & 29 \\
\hline Placing of small stumps in the bunds & 71 & 37 & 20 \\
\hline Ploughing and sowing across the slope & 22 & 83 & 23 \\
\hline
\end{tabular}

Table 3. Traditional methods for maintaining the fertility of soil

\begin{tabular}{|l|c|c|c|}
\hline \multirow{2}{*}{ Methods } & \multicolumn{3}{c|}{ Responses (n=128) } \\
\cline { 2 - 4 } & Yes & No & Not answered \\
\hline Use of farmyard manure & 93 & 28 & 7 \\
\hline Use of goat dung/urine & 34 & 68 & 26 \\
\hline Burning of leaves and branches & 62 & 47 & 19 \\
\hline Mulching & 73 & 23 & 32 \\
\hline Dividing land or making terraces & 49 & 52 & 27 \\
\hline
\end{tabular}

While making bunds, the local people also kept some stones along the bunds to protect the soil. The bunds were often fenced with logs of Shorea robusta, Tectona grandis and Chloroxylon swietenia. They also kept some leaves, particularly of Tectona grandis and Oryza sativa, as mulch in the agricultural field. The stumps of Oryza sativa were also placed in the bunds to control the soil erosion and high water runoff. About $55 \%$ interviewees admitted practicing this technique. In case of high rainfall they made outlet from the bunds for water otherwise the large volume of water altered and destroyed the bunds. To check the soil nutrients from running down with water, the local people often tilled the agricultural land. If the crops were already sown and grown then they tilled the boundaries of crop field that also helped in checking the soil to erode as pointed out by $18 \%$ of respondents. Besides, the stone wall was also made along the land boundary to control the soil erosion from the cropping land. Some people have also constructed earthen wall in order to protect the soil as well as to stop the livestock.

\subsubsection{Maintaining soil moisture}

Moisture being an important component of the agricultural practices farmer was cautious to maintain it and kept it in mind starting from sowing of seeds to the harvesting of crops. Local people believed that optimum moisture content in land was required for proper germination of seeds. It was believed that both excess of moisture and lack of moisture imposed negative impacts on seeds germination. They leveled the land by leveler just after tilling. The land was tilled in such a way so that the soil moisture may be retained. Besides, soil types also determined the moisture contents as Kadialtori, a high textured soil, kept moisture for very short period and Bhurbhuria and Rateli kept moisture for long time. The selection 
of crops grown was also based on the soil moisture. Some landraces of Oryza sativa and Triticum aestivum including Cicer arietinum were relatively long duration crops and required high moisture, whereas other landraces of rice such as 'Lalei' and 'Batra' were short duration and required less moisture. In the presence of high moisture contents farmers avoided sowing of seeds until moisture decreased to desired level. The excess water was also removed from field in order to maintain the required soil moisture.

\subsubsection{Applying manure}

As and when required, the villagers applied farmyard manure in the respective soil types to enhance soil fertility before tilling. The organic material with cow dung was only used after 2 to 3 years of its decomposition, which was considered good manure. Mainly the farmyard manure was applied in the sandy, Bhurbhuria, Chikti and Teloala soils, which were poor in nutrients. In black soil low amount of farmyard manure was applied, as it was believed that black soil was rich with nutrients. The traditional knowledge of farmers helped them to determine the proportion of organic components in the soil and hence to identify the soil quality and soil fertility. Soil texture and colours were some of the factors for recognizing the soil quality and fertility. Traditionally, they often tested the soil quality by mixing it with water. If the soil easily got mixed with water it was considered less fertile. If the soil took time to absorb the water it was considered good quality soil for cultivation. In case the soil was less fertile high quantity of organic manure was applied as the people believed that high application of organic manure proportionately increased the soil fertility.

The majority of local people (72\%) have reported using farmyard manure as good organic manure in their agricultural land (Table 3). Since 14\% of respondents did not have livestock, they used to collect cow dung from grazing land areas, as cows were left loose for grazing in such areas during daytime. The pellets and urine of sheep and goats were also applied as manure for crops. Though sheep and goats pellets were considered good organic manure and also better than cow dung, only $27 \%$ of respondents had goats and sheep, hence its supply was low.

\section{Discussion}

The broad classification of Indian soil type has placed the soil of present study area in the category of black soil or black cotton soil. Though the black cotton soil or Bhurbhuria soil is the most dominant soil in the state of Madhya Pradesh (Bhattacharyya et al., 2007), at local level there are variations in the soil types as the local people of PBR have, traditionally, identified and classified 16 types of soil on the basis of soil texture, soil colour, water retaining capacity of soil and terrain types (Table 1). The specific soil types have been identified and earmarked by the local people for cultivation of selected crops depending upon the quality and fertility of soil. Some of the soil types such as Kasaimitti, Barimitti and Lalmitti were generally not used for cultivation as these soil types resembled laterite soil and had poor water retaining capacity. Bhurbhuria or black cotton soil was considered the most fertile soil by the local people, which shrinks and develops cracks during dry season. Such cracks help in air circulation. The soil organic carbon varies from $2-5 \%$ in black soil of Madhya Pradesh and once it is brought under cultivation the organic carbon content of soil declines sharply (Bhuse et al., 2001; Bhattacharyya et al., 2007). Since repeated crop cultivation exhausts the fertility of soil, the local people have designed various techniques for maintaining the soil fertility.

Over the years of experience, the local people of PBR have developed and accumulated knowledge in order to maintain the soil fertility by adopting optimum tillage methods based on the soil types. Gathering of crop residues and other organic matters including leaves and branches on the soil surface and implementation of spatial and temporal crop rotations may not only benefit the soil fertility but also deal with prevailing adversities of climatic conditions. Intensive tillage is 
known to lead to the gradual decline in soil organic matter through accelerated oxidation subsequently reduce the soil capacity to regulate water and nutrient supplies to the desired crops (Ghosh et al., 2010). Research conducted in other parts of India has demonstrated advantages of crop residues retention on soil surface, especially to improve the soil quality (Sangar and Abrol, 2005). The system of raising crops with minimum disturbance to the soil significantly improves water availability in the soil (Ghosh et al., 2010); however, it may vary with soil types and environmental conditions, as perceived by the local farmers of PBR. Recently in 2011, because of late arrival of monsoon and also ignoring traditional ecological knowledge in planting of seeds in a hurry before sufficient moisture availability in soil are blamed for Soybean (Glycine max) crop failure in an adjacent state Maharashtra (Pallavi, 2011).

The farmers in PBR, traditionally, do not remove all the trees and let some trees grow in the agriculture land, especially ethnobotanically useful species such as Madhuca indica. Availability of tree species in the farmland, besides providing organic matter to the soil, may also help to prevent the soil erosion (Kala, 2010). Such trees also act as windbreaks and protect the soil erosion. Terrace farming, mulching, marking land boundary and small bunds, erecting small stumps in the bunds, growing of tussock grasses along the border and bunds, identifying soil nature and types, and application of manure based on the nature of soil are one way or others help to maintain the nutrients in the soil and ultimately the soil fertility. Some similar observations have been made on the soil conservation techniques adopted by indigenous communities elsewhere (Kala et al., 2008; Tekwa et al., 2010), which suggest the viability and relevance of traditional practices for sustainable crop production. Besides, the traditional knowledge of testing soil quality by use of water not only helps to determine the quantity of manure to apply in the soil but also maintain the soil fertility and suitability of crops to be cultivated in such soils.
Soil colour has played an important role in classification of soils by local people of PBR apart from soil texture. This observation in PBR resembles many indigenous communities across the world such as the Baruya people of New Guinea (Ollier et al., 1971), indigenous people of Thailand, Java and Indonesia (Marten and Vityakon 1986), Mebengokre people of Brazil (Posey, 1989), Shipibo people of Peru (Behrens, 1989), Andes of Ecuador (Knapp, 1991), and Chiapas of South Mexico (Bellon and Taylor, 1993). In general, the local people consider dark soil as more fertile than light soil. Based on colour, the farmers in Niger of Western Africa have made three colour classes of soil: black soil (the most fertile and contains relatively high organic contents), white soil (the black soil changes into white through repeated cultivation and erosion of nutrients), and red soil (further degradation of white soil) (TaylorPowell et al., 1991; Ettema, 1994). Reduced crop yield is one of the traditionally known indicators of declining soil fertility. In the present study area where rainfall is low and erratic, conserving soil moisture is important for desired crop production. Therefore, the local people perception of soil fertility is also related to the water holding capacity of respective soil type. Since the crop production depends on a range of other factors, it is argued that the low crop yields may not be a sole and perfect indicator of declining soil fertility (Corbeels et al., 2000).

It has been reported that 6000 million tones of productive soil is lost every year from about 80 million hectares of cultivated land in India (Husain, 2003). Thus, erosion results in the loss of nutrients and weakening of soil fertility. The traditional ecological knowledge of local people in maintaining the soil fertility may mitigate this widespread calamity, if documented, analyzed and applied properly. The success of any soil conservation programme, as initiated by the Government, depend on the farmers as they have been the custodian of soil conservation work and understand traditionally the causes of nature of soil erosion and associated problems. It is believed that the active participation of farmers in soil conservation programmes is essential for the success of such programmes. 


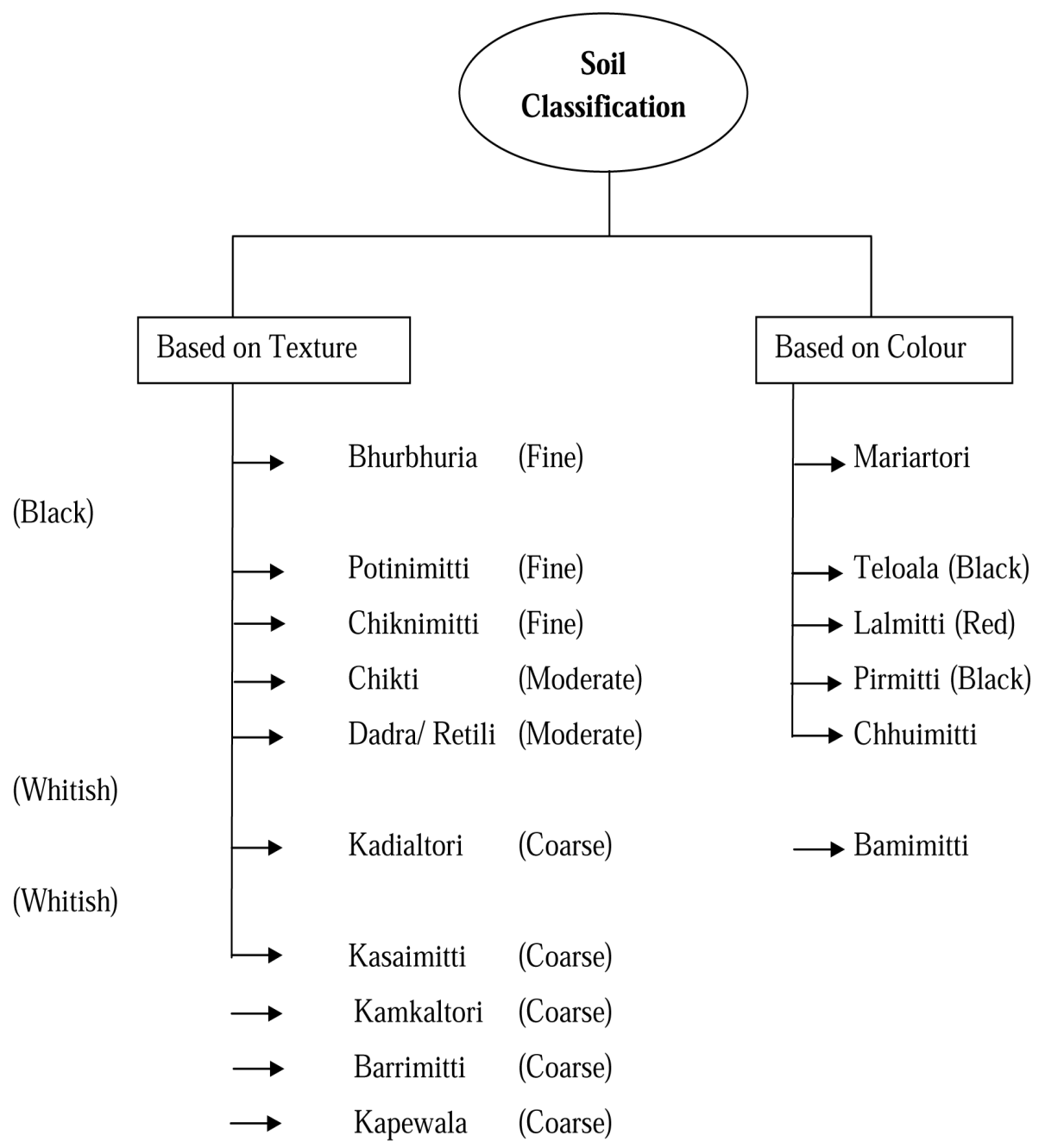

Figure 1.0 Soil types as classified traditionally by local people of Pachmarhi Biosphere Reserve 


\section{Conclusion}

It seems that soil texture and colour are the two basic determinants in classifying soil by various indigenous communities. The traditional soil conservation and management practices in PBR are well knitted and interwoven with the cultures, belief systems and available resources. They still use organic materials to increase the soil fertility; though they are aware of modern fertilizer. In order to increase the soil fertility, the local people either plant or do not remove some of the existing tree species from the agricultural field. The traditional practices appeared viable, relevant, and time tested in conserving soil for sustainable crop production in this study. The traditional practices of soil conservation and management are environmentfriendly and hence the community must be encouraged to continue such practices in view of the ongoing consequences of climate change. Besides, the traditional wisdom should be documented in view of its importance in developing environment-friendly models for resource augmentation and sustainable management.

\section{Acknowledgement}

I thank Director, Indian Institute of Forest Management (IIFM), for providing support. Dr. Ashish David and Dr. M.D. Omprakash - Faculty IIFM - are acknowledged for intellectual support and Bhubaneswar Saber for helping in field-data collection. The project was funded under the grant IIFM/RP-Int./CPK/2009-11/04.

\section{References}

Behrens, C.A. 1989. The scientific basis for Shipibo soil classification and land use: changes in soilplant associations with cash cropping. American Anthropologist. 91, 83-100.
Bellon, M.R., Taylor, J.E. 1993. Folk soil taxonomy and the partial adoption of new seed varieties. Economic Development and Cultural Change. 41 (4), 762-786.

Berkes, F. 1999. Sacred Ecology: Traditional Ecological Knowledge and Resource Management. Taylor and Francis, Philadelphia.

Berkes, F., Colding, J., Folke, C. 2000. Rediscovery of traditional ecological knowledge as adaptive management. Ecological Applications. 10 (5), $1251-1262$.

Bhattacharyya, T., Chandran, P., Ray, S.K., Mandal, C., Pal, D.K., Venugopalan, M.V., Durge, S.L., Srivastava, P., Dubey, P.N., Kamble, G.K., Sharma, R.P., Wani, S.P., Rego, T.J., Pathak, P., Ramesh, V., Manna, M.C., Sahrawat, K.L. 2007. Physical and chemical properties of selected benchmark spots for carbon sequestration studies in semi-arid tropics of India. Global Theme on Agroecosystems Report no. 35. International Crops Research Institute for the Semi-Arid Tropics, Patancheru, Andhra Pradesh, India.

Bhuse, S.R., Vaidya, P.H., Bhattacharyya, T., Pal, D.K. 2001. An improvised method to determine clay smectite in Vertisols. Clay Research. 20, 65-72.

Bonny, P., Vijayaragavan, K. 2001. Adoption of sustainable agricultural practices by traditional Rice growers. Journal of Tropical Agriculture. 39, 151-156.

Cleveland, D.A. 1998. Balancing on a Planet: Toward an Agricultural Anthropology for the Twenty-First Century. Human Ecology. 26, 2, 323-340.

Corbeels, M., Shiferaw, A., Haile, M. 2000. Farmers' knowledge of soil fertility and local management strategies in Tigray, Ethiopia. Managing Africa's Soils No. 10. Russell Press, Nottingham. 
EPCO, 2001. Pachmarhi Biosphere Reserve. Environmental Planning and Co-ordination Organization. Bhopal, India.

Ettema, C.H. 1994. Indigenous soil classifications. University of Georgia, Athens GA, USA.

Gadgil, M., Berkes, F., Folke, C. 1993. Indigenous knowledge for biodiversity conservation. Ambio. 22, 151-156.

Ghosh, P.K., Das, A., Saha, R., Kharkrang, E., Tripathi, A.K., Munda, G.C., Ngachan, S.C. 2010. Conservation agriculture towards achieving food security in North East India. Current Science. 99 (7), 915-921.

Haverkort, B. 1995. Agricultural development with a focus on local resources: ILEIA's view on indigenous knowledge. In Indigenous Knowledge Systems: The Cultural Dimensions of Development, edited by D.M. Warren, D. Brokensha and L.J. Slikkerveer. Kegan Paul International, London, pp 34- 39.

Husain, Z. 2003. Environmental Issues of North East India. Regency Publications, New Delhi.

Jayson. E.A. 1990. An ecological survey at Satpura national park, Pachmarhi and Bori sanctuaries, Madhya Pradesh. Indian Journal of Forestry. 13, 4, 288-294.

Kala, C.P. 2010. Status of an indigenous agro-forestry system in changing climate: A case study of the middle Himalayan region of Tehri Garhwal, India. Journal of Forest Science. 56, 8, 373-380.

Kala, C.P. 2011. Traditional ecological knowledge, sacred groves and conservation of biodiversity in the Pachmarhi Biosphere Reserve of India. Journal of Environmental Protection. 2, 7, 967-973.

Kala, C.P. 2012. Traditional ecological knowledge and conservation of ethnobotanical species in the buffer zone of Pachmarhi Biosphere Reserve, Madhya Pradesh. Indian Institute of Forest Management, Bhopal, India. 194 pp.

Kala, C.P., Dollo, M., Farooquee, N.A., Choudhury, D.C. 2008. Land-use management and wet-rice cultivation (Jebi Aji) by the Apatani people in Arunachal Pradesh, India. Outlook on Agriculture. 37, 2, 125-130.

Knapp, G. 1991. Andean Ecology - Adaptive Dynamics in Ecuador. Westview Press, Dellplain Latin American Studies, No. 27.

Marten, G.G., Vityakon, P. 1986. Soil management in traditional agriculture. In Traditional Agriculture in Southeast Asia: A Human Ecology Perspective edited by G.G. Marten. Boulder, CO. pp. 199-225.

Ollier, C.D., Drover, D.P., M. Godelier 1971. Soil knowledge among the Baruya of Wonenara, New Guinea. Oceania. 42. 1, 33-41.

Pallavi, A. 2011. Seeds of failure. Down to Earth. 20, 7, 12-13.

Posey, D.A., 1989. Alternatives to forest destruction: lessons form the Mebengokre Indians. The Ecologist. 19, 6, 241-244.

Rajasekaran, B., Whiteford, M.B. 1992. Rice-crab production system: The role of indigenous knowledge in designing food security policies. Food Policy. 18, 3, 237-47.

Ramakrishnan, P.S. 2002. What is traditional ecological knowledge? In Traditional Ecological Knowledge for Managing the Biosphere Reserve in South and Central Asia edited by P.S Ramakrishnan et al. Oxford University Press, New Delhi, pp 1-10.

Sanders, D. 2004. Soil conservation. In Land Use, Land Cover and Soil Sciences edited by Willy $\mathrm{H}$. Verheye. UNESCO, Eolss Publishers, Oxford,UK. 
Sangar, S., Abrol, I.P. 2005. Conservation agriculture for transition to sustainable agriculture. Current Science. 88, 686-687.

Schmidt, P.M., Peterson, M.J. 2009. Biodiversity conservation and indigenous land management in the era of self determination. Conservation Biology. 23 (6), 1458-1466.

Singh, V.P., Kaul, A. 2002. Biodiversity and vegetation of Pachmarhi hills. Scientific Publishers, Jodhpur, India.
Taylor-Powell, E., Manu, A., Geiger, S.C., Ouattara, M., Juo, A.S.R. 1991. Integrated management of agricultural watersheds: land tenure and indigenous knowledge of soil and crop management. Tropical Soils Bulletin, 91-04. Texas, 30 p.

Tekwa I.J, Belel, M.D., Alhassan, A.B. 2010. The effectives of indigenous soil conservation techniques on sustainable crop production. Australian Journal of Agricultural Engineering. 1, 3, 74-79. 